\title{
Archaeological Investigations at the New Hope Site (41FK107) at Lake Bob Sandlin, Franklin County, Texas
}

Bo Nelson

Heritage Research Center, Stephen F. Austin State University

Timothy K. Perttula

Heritage Research Center, Stephen F. Austin State University

LeeAnna Schniebs

Follow this and additional works at: https://scholarworks.sfasu.edu/ita

Part of the American Material Culture Commons, Archaeological Anthropology Commons, Environmental Studies Commons, Other American Studies Commons, Other Arts and Humanities Commons, Other History of Art, Architecture, and Archaeology Commons, and the United States History Commons

Tell us how this article helped you.

This Article is brought to you for free and open access by the Center for Regional Heritage Research at SFA ScholarWorks. It has been accepted for inclusion in Index of Texas Archaeology: Open Access Gray Literature from the Lone Star State by an authorized editor of SFA ScholarWorks. For more information, please contact cdsscholarworks@sfasu.edu. 


\section{Archaeological Investigations at the New Hope Site (41FK107) at Lake Bob Sandlin, Franklin County, Texas}

\section{Creative Commons License}

\section{(c) (1) \&}

This work is licensed under a Creative Commons Attribution-NonCommercial 4.0 International License 


\title{
Archaeological Investigations at the New Hope Site (41FK107) at Lake Bob Sandlin, Franklin County, Texas
}

\author{
Bo Nelson and Timothy K. Perttula, with a contribution by LeeAnna Schniebs
}

\section{Introduction}

The New Hope site (41FK107) is a prehistoric site located on a toe slope landform overlooking the Big Cypress Creek valley (Figure 1), the latter now inundated by Lake Bob Sandlin. An old creek channel lies about $100 \mathrm{~m}$ to the east. Previous investigations reported by Nelson and Perttula (2003:43-44) indicate that the New Hope site covers about 2.5 acres, and was occupied during Late Paleoindian, Middle-Late Archaic, Woodland, and post-A.D. 800 Caddo times.

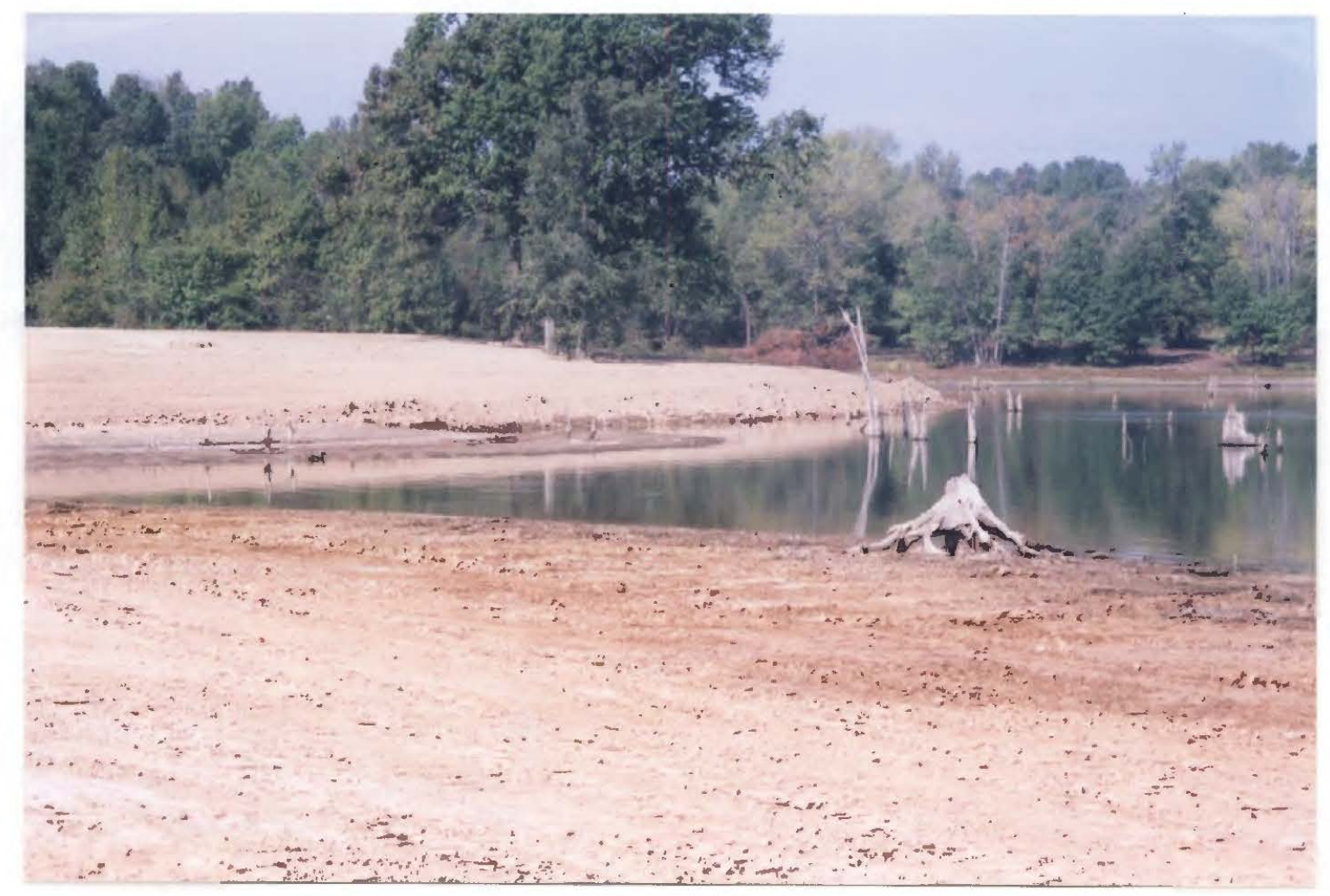

Figure 1. Looking north at the eastern end of the New Hope site (41FK107).

The Caddo occupation was the principal occupation of the site. Nelson and Perttula (2003:43) noted at least 20-30 grave-sized looter holes there, and there have been reports that prehistoric burials have eroded out along the Lake Bob Sandlin shoreline. Two vessels in a private collection from the site are small bowls $(5.2-5.5 \mathrm{~cm}$ in height and 12.3-14.4 cm orifice diameters) with tab tails on opposing sides of the vessel lip. One of the vessels has five horizontal engraved lines on the rim, and the other is plain. 


\section{Investigations}

In October 2005, Nelson was at Lake Bob Sandlin and noticed that some earthmoving activities with heavy machinery were in progress at the New Hope site about $45 \mathrm{~m}$ from the current Lake Bob Sandlin shoreline (Figure 2). This is on property owned by Kenneth L. Beck. With his permission, the scraped area was examined for evidence of cultural features and archaeological deposits.

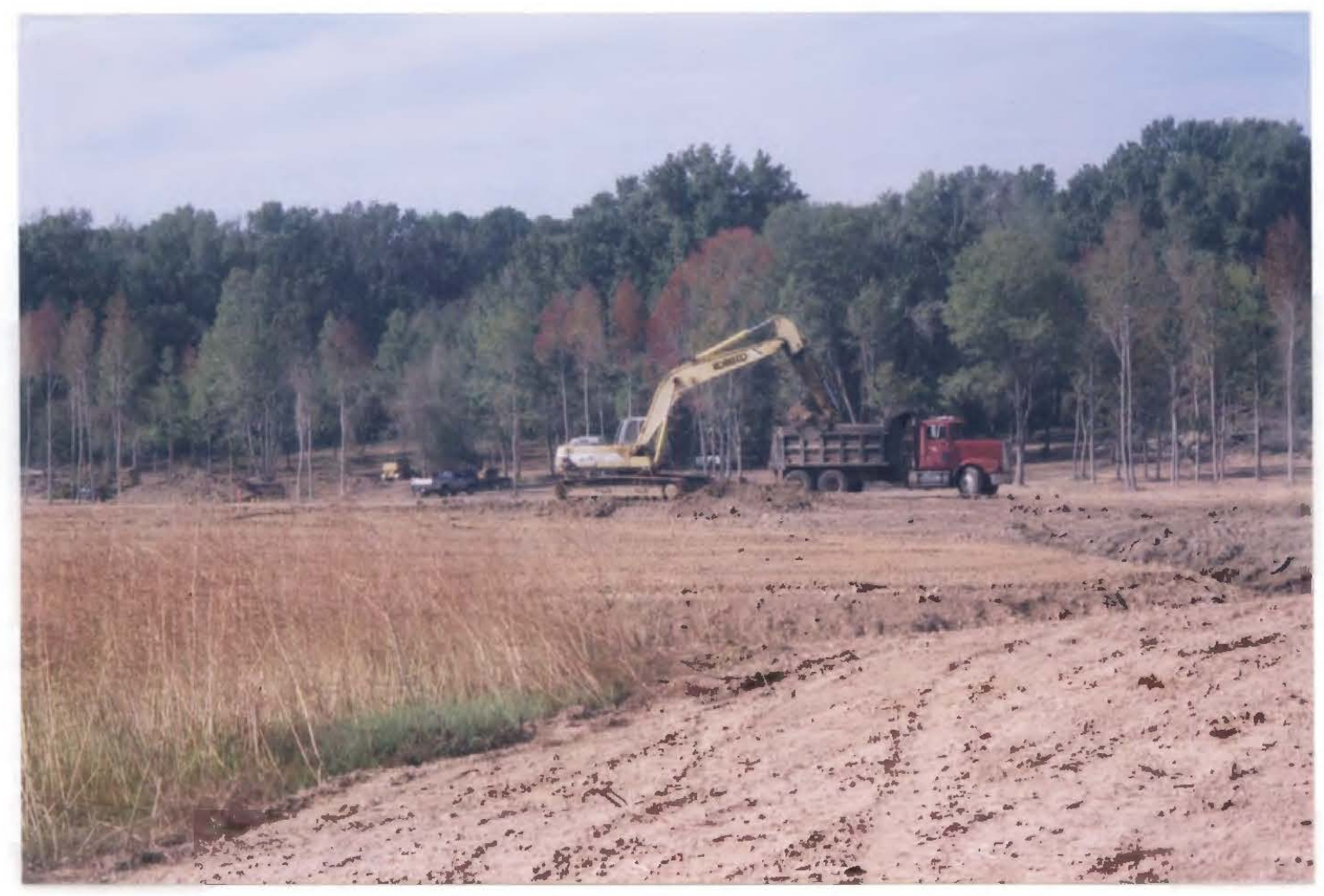

Figure 2. The area of earthmoving activities at the New Hope site, looking north.

The investigations of the scraped area consisted of the shovel skimming and troweling of a ca. $25 \times 15 \mathrm{~m}$ area to search for evidence of preserved cultural features. When likely features were noted, being marked by a dark grayish-brown stain that was often charcoal-flecked, they were mapped in plan view and cross-sectioned to determine if the stains were cultural features. Profiles were then drawn of the exposed features, and their fills were either screened through 1/4-inch screen mesh (in the case of post holes and small pits) or the feature fill (from one hearth, Feature 2) was collected in its entirety for fine-screening through $1 / 16$-inch screen mesh. 


\section{Cultural Features and Radiocarbon Date}

During the 2005 examination of the New Hope site, a very large grayish-brown stain was noted by Nelson at the eastern edge of the machine-scraped area. This is about $20-40 \mathrm{~m}$ from the Lake Bob Sandlin shoreline. This stain, measuring $80 \times 96 \mathrm{~cm}$ in size (Figure 3), was cleared and cross-seetioned at approximately $20 \mathrm{~cm}$ bs (the depth of the machine scraping). These excavations indicated that this large stain (Feature 2) is a basinshaped hearth feature that extends from $20-43 \mathrm{~cm}$ bs; it was excavated aboriginally almost $18 \mathrm{~cm}$ into the clay B-horizon. The basin has relatively straight sides and a flat base, with a thin layer of thermally oxidized soil on its base and lower hearth basin (Figure 4). Above this is a $6-8 \mathrm{~cm}$ thick ash layer, overlain by a very dark grayish-brown sandy loam (15-20 cm thick) with flecks and lenses of charcoal. Charred nutshells from this zone were submitted for radiocarbon analysis.

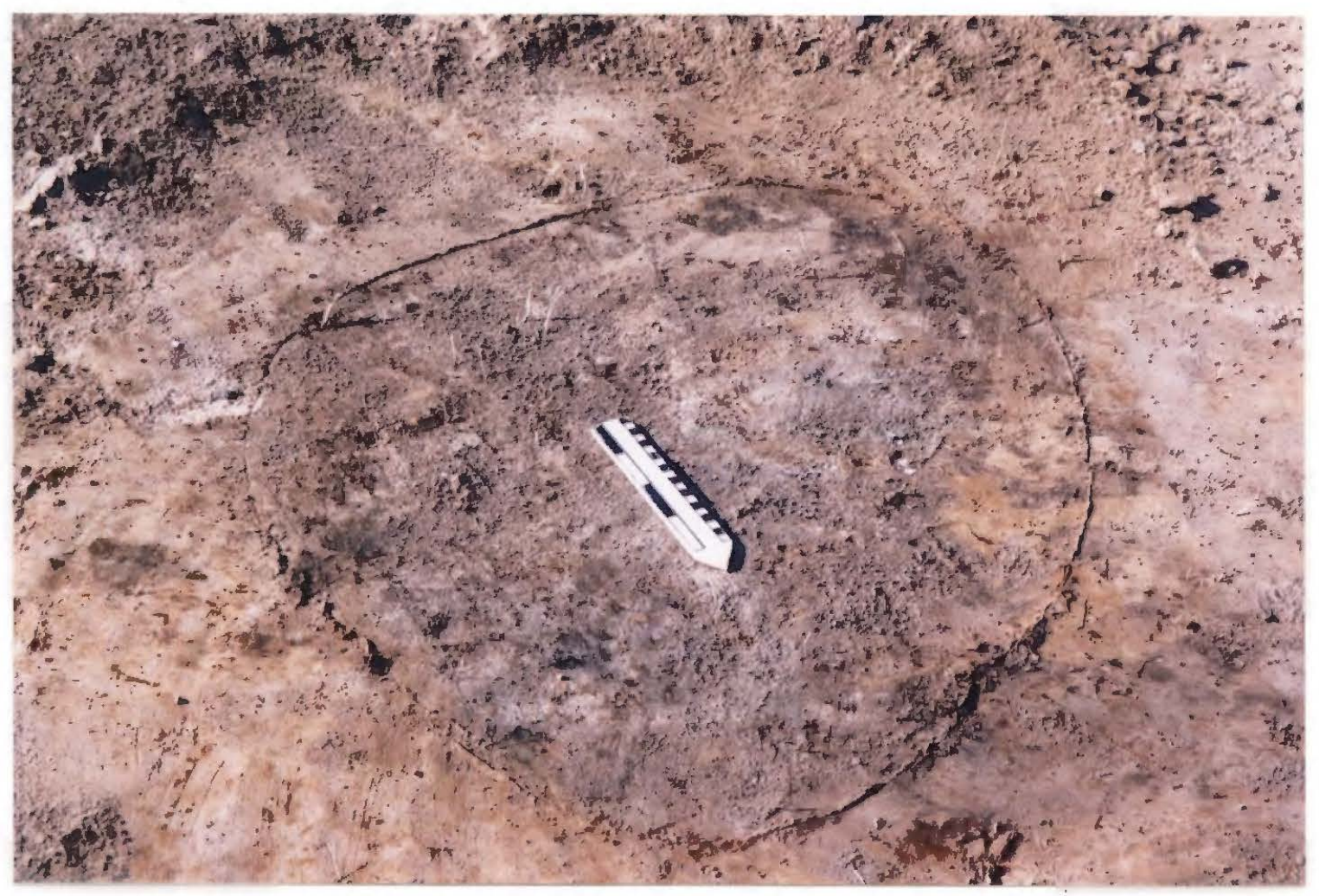

Figure 3. Looking at the top of the exposed basin hearth (Feature 2) at the New Hope site.

Charred Hickory (Carya sp.) nutshells from the Feature 2 fill were submitted to Beta Analytic, Inc. for radiocarbon dating (Appendix 1). The nutshells in the feature have an age range from cal. AD $1280-1420$ at 2 sigma (95\% probability), with calibrated intercepts of AD 1310, AD 1360, and AD 1390 (Beta-210581). 


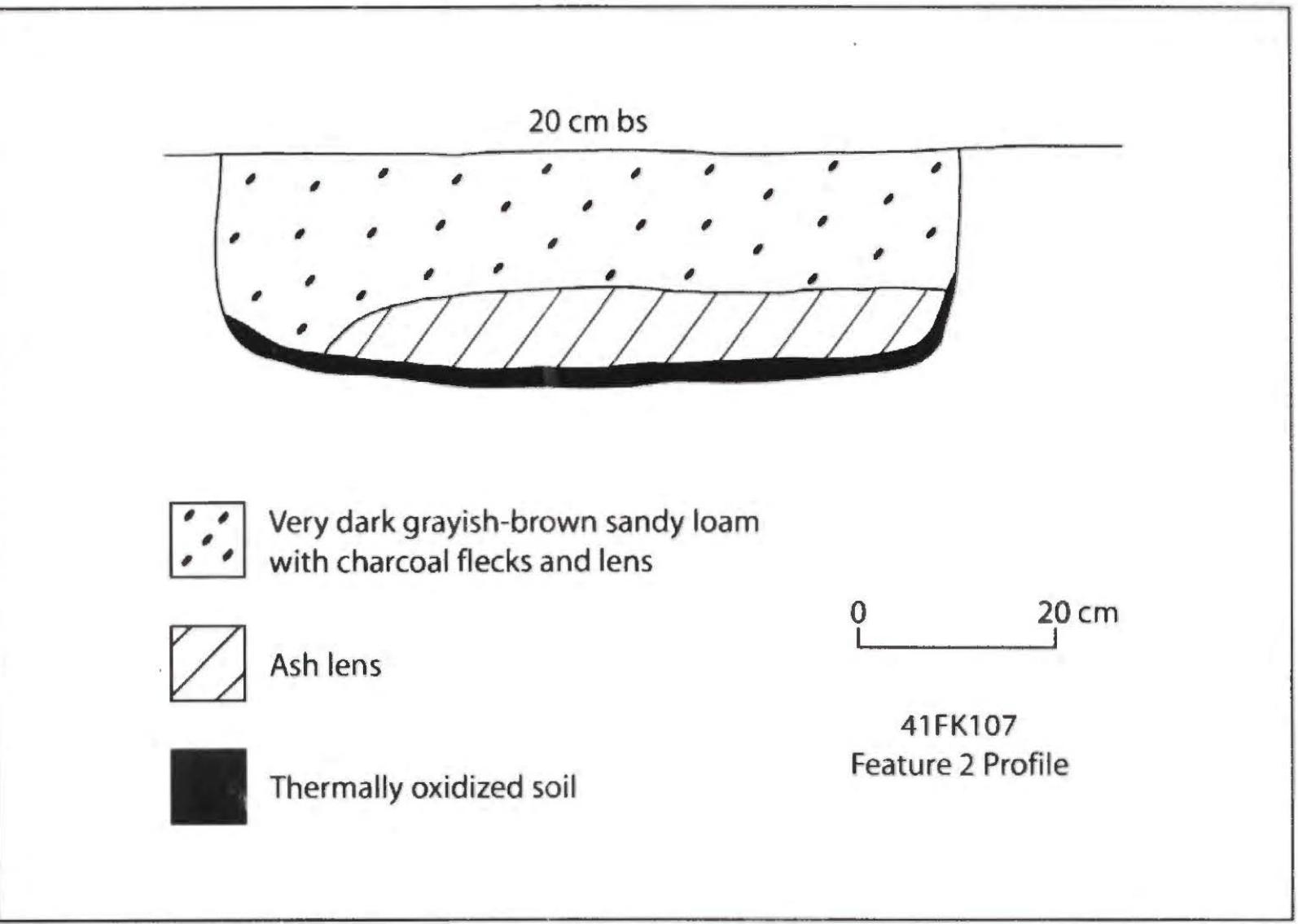

Figure 4. Profile of Feature 2.

Further shovel skimming around Feature 2 found a number of postholes $(n=12)$ and small pit features $(n=3)$ (Figure 5). Nine of the post holes form a portion of an estimated $8.8 \mathrm{~m}$ circular arc around the Feature 2 hearth. The post holes average $19.1 \mathrm{~cm}$ in diameter, and they extend on average to $35 \mathrm{~cm}$ bs, being anchored in the B-horizon clay. They have a dark grayish-brown to very dark grayish-brown sandy loam fills with charcoal flecks. PH 6 (see Figure 5) contained considerable amounts of charcoal, and may represent a charred post. These post holes are wall support-sized and would have held wood posts. The post hole arc made up the walls of a prehistoric Caddo circular grass-covered structure or household dwelling.

There are also three post holes and three pit features outside of the structure wall arc (Figure 5). The pit features probably represent an outdoor work area associated with the structure. The extra-mural post holes are 20\% Iarger in size (average diameter of 22.7 $\mathrm{cm}$ ) than the wall support posts and may have been parts of racks or other outdoor work facilities. PH 14 contains considerable amounts of charcoal and may be a charred post. The three pit features have charcoal-stained fills. They range from $30-35 \mathrm{~cm}$ in diameter and extend from $35-50 \mathrm{~cm}$ bs, well into the clay B-horizon. 


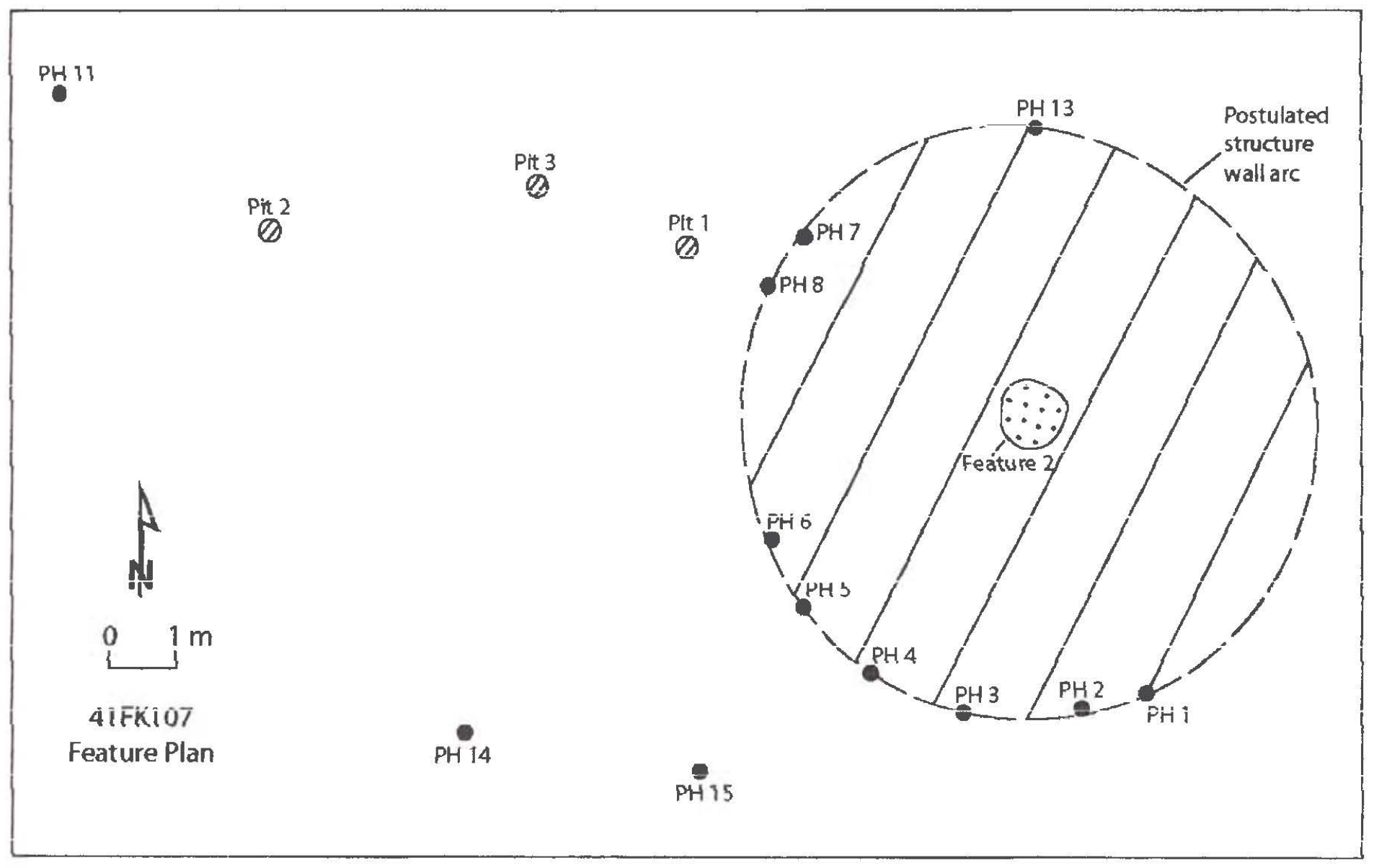

Figure 5. Plan of features at the New Hope site, including postulated structure wall arc. 


\section{Material Culture}

Only 49 prehistoric artifacts were recovered from the 2005 archaeological investigations of features at the New Hope site. Another 223 artifacts were collected from the surface (Table 1). Most of the recovered artifacts are plain and decorated ceramic sherds or pieces of lithic debris.

Table 1. Inventory of Artifacts and other Remains from the New Hope site (41FK107).

\begin{tabular}{|c|c|c|c|c|c|c|c|c|c|}
\hline Artifact Class & Surface & Fea. 2 & Pit 2 & Pit 3 & PH1 & PH5 & PH6 & PH8 & Totals \\
\hline \multicolumn{10}{|l|}{ CERAMICS } \\
\hline Plain base & 8 & 1 & - & - & - & - & - & - & 9 \\
\hline Plain body & 95 & 14 & I & - & 3 & 1 & - & 1 & 115 \\
\hline Plain rim & 7 & - & - & - & - & - & - & - & 7 \\
\hline Decorated rim & 3 & 1 & - & - & - & - & - & - & 4 \\
\hline Lip notched rim & 1 & - & - & - & - & - & - & - & 1 \\
\hline Decorated body & 41 & 5 & - & - & 1 & - & 1 & - & 48 \\
\hline Clay coil & - & 1 & - & - & - & - & - & - & 1 \\
\hline \multicolumn{10}{|l|}{ LITHICS } \\
\hline Dart point & 5 & - & - & - & - & - & - & - & 5 \\
\hline Biface & 1 & - & - & 1 & - & - & - & - & 2 \\
\hline Core & 1 & - & - & - & - & - & - & - & 1 \\
\hline Lithic debris & 61 & 14 & - & - & 1 & - & 2 & - & 78 \\
\hline $\begin{array}{l}\text { Fire-cracked } \\
\text { Rock }\end{array}$ & - & 1 & - & - & - & - & - & - & 1 \\
\hline Animal bone & - & 281 & - & - & - & - & - & - & 281 \\
\hline Mussel shell & - & + & - & - & - & - & - & - & + \\
\hline N & 223 & 318 & 1 & I & 5 & 1 & 3 & 1 & 553 \\
\hline
\end{tabular}

Probably the majority of the lithic artifacts from the site are the product of the Middle-Late Archaic and Woodland period occupations, as attested by the numerous dart points found at the site during this and earlier archaeological investigations (see Nelson and Perttula 2003). These earlier occupations are marked by two contracting stem Gary points of gray chert and petrified wood found in the 2005 surface collection, along with a novaculite straight-stemmed point (probably of the Kent type), and single examples of Yarbrough and Wells points made from quartzite. In earlier surface collections (Nelson and Perttula 2003:44), there were two quartzite dart point blade and tip fragments, two Gary points (novaculite and claystone/siltstone), a broad parallel stemmed dart point, and 
three Late Paleoindian points (including two Dalton points) of novaculite and dark grayish-brown chert.

Other chipped lithic tools from the site include two early stage bifaces, one made of quartzite and the other of petrified wood (see Table 1). There is also one core of brownish-gray chert, 78 pieces of lithic debris, and a single piece of fire-cracked rock. The lithic debris from the features includes quartzite $(n=10)$, brown chert $(n=3)$, red chert $(n=2)$, and petrified wood $(n=2)$. The presence of these lithic debris raw materials indicate that the Caddo occupants of the New Hope site utilized locally available lithic gravel sources.

The only clearly identifiable prehistoric Caddo chipped stone tools from the New Hope site are two quartzite arrow points (Nelson and Perttula 2003:44). One is a Catahoula point with broad rectangular barbs and the other is a corner-notched arrow point.

The Caddo ceramic sherds from the New Hope site are tempered with grog (i.e., crushed sherds or pieces of fired clay). Approximately $10 \%$ of the sherds also have crushed pieces of hematite added to the paste. The one clay coil found in Feature 2 indicates that some (if not all) ceramic vessels were made on-site.

The 53 decorated sherds in the 2005 surface collection and feature investigations are from vessels with punctated (30.2\%), incised (24.5\%) and engraved (28.3\%) elements/motifs. Other decorative methods represented in the 2005 New Hope sherd collections are red-slipped body sherds $(7.5 \%)$, brushed (3.8\%), pinched-ridged (3.8\%), and lip notched (1.9\%) (Table 2). The few rim sherds include two with vertically incised lines and two others with opposed incised lines. These may be from Dunkin Incised vessels (cf. Suhm and Jelks 1962: Plate 19). Other decorated utility ware body sherds have cross-hatched incised lines $(n=2)$, opposed incised lines $(n=1)$, closely-spaced parallel incised lines $(n=2)$, rows of tool punctations $(n=8)$ and fingernail punctates $(n=3)$, and free or randomly placed fingernail punctations $(n=5)$. Two utility ware sherds have parallel brushing marks on them, probably on the body of cooking jars.

Table 2. Decorated sherds from the New Hope site.

\section{Decorative Method 2003 Surface 2005 Surface 2005 Features N}

\section{UTILITY WARES}

$\begin{array}{lllll}\text { Punctated } & 104 & 16 & - & 120 \\ \text { Incised } & 28 & 10 & 3 & 41 \\ \text { Punctated-Incised } & 5 & - & - & 5 \\ \text { Appliqued } & 1 & - & - & 1 \\ \text { Brushed } & 3 & 2 & - & 5 \\ \text { Pinched } & - & 1 & 1 & 2\end{array}$


Table 2. Decorated sherds from the New Hope site, cont.

Decorative Method 2003 Surface 2005 Surface 2005 Features N

\begin{tabular}{lllll}
\hline Lip notched & - & 1 & - & 1
\end{tabular}

FINE WARES

$\begin{array}{lllll}\text { Engraved } & 16 & 11 & 4 & 31 \\ \text { Red slipped } & 1 & 4 & - & 5 \\ \text { Ripley Engraved* } & 1 & - & - & 1\end{array}$

$\begin{array}{lllll}\text { Totals } & 159 & 45 & 8 & 212\end{array}$

*from Late Caddo Titus phase use of the New Hope site

Among the fine wares are body sherds with an exterior red slip, as well as body sherds with parallel and curvilinear engraved lines $(\mathrm{n}=6)$ from carinated bowls and bottles. One body sherd has a hatched engraved zone or ladder design. One body sherd is from a Holly Fine Engraved vessel with diagonal engraved lines adjacent to a triangular excised area (see Suhm and Jelks 1962: Plate 39). The fine wares comprise $36 \%$ of the decorated sherds from the 2005 archaeological investigations at the New Hope site (see Table 2).

The larger sample of decorated sherds from the New Hope site-including the surface collection documented by Nelson and Perttula (2003) as well as the 2005 investigations-comprise 212 sherds and one vessel tab tail (see Figure 2). There are a total of 604 plain sherds. The plain/decorated sherd ratio for the combined New Hope Caddo ceramic assemblage is 2.85 .

Overall, more than $82 \%$ of the decorated sherds are from utility ware vessels, particularly ceramic vessels decorated with tool and fingernail punctations or horizontal, diagonal, opposed, or cross-hatched incised lines. Fine wares comprise $17.1 \%$ of the decorated sherd assemblage, including red slipped vessels (bowls) and engraved vessels with horizontal and diagonal engraved lines. Other fine wares have broadly-spaced curvilinear engraved lines as well as sherds with curvilinear zones or panels filled with cross-hatched or diagonal lines. These engraved sherds with cross-hatched and hatched zones - as well as sherds with hatched ladders - are commonly present in Middle Caddo ceramic assemblages across much of Northeast Texas, including the Big Cypress Creek basin (Perttula 2004:390; Nelson and Turner 1997:1, 4). 


\section{Faunal Remains from the New Hope Site (41FK107), by LeeAnna Schniebs}

Investigations at the New Hope site in 2005 recovered 281 very small faunal specimens from a Feature 2 (hearth) fine screen sample. Total weight of the faunal sample is only $6.26 \mathrm{~g}$.

Turtle is the only identifiable animal in the sample (Table 3 ). The small mammal bones are likely the remains of rabbit or squirrel, and the large mammal bones are probably the remains of deer. These are the most common animals found in prehistoric Caddo faunal assemblages, and the main subsistence animals preferred by the Caddo. All of the bone fragments are burned and highly fragmented, and they are likely the result of trash disposal into the hearth fill.

Table 3. Faunal remains from Feature 2 at the New Hope site (41FK107).

\begin{tabular}{llllll}
\hline Taxon & No. & Element/Portion & Burning Weight $(\mathrm{g})$ & Comments \\
& 1 & shell fragment & black 0.05 & \\
\hline Turtle & 2 & shell fragment & white 0.05 & rabbit? \\
Turtle & 2 & metapodial, distal & white 0.06 & \\
Small mammal & 4 & long bone fragment & white & 0.10 & \\
Small mammal & 70 & unidentifiable & white & 0.80 & \\
Small mammal & 194 & unidentifiable & black & 3.70 & \\
Small mammal & 8 & unidentifiable & black & 1.50 & \\
Large mammal & & & & &
\end{tabular}

\section{Summary and Conclusions}

Archaeological investigations in 2005 at the New Hope site (41FK107), as well as earlier work reported by Nelson and Perttula (2003), indicate that it has extensive prehistoric Caddo archaeological remains. These include habitation deposits and a cemetery area. The 2005 work reported on here exposed post holes and a central hearth from a large circular structure in an area that had been shallowly scraped with heavy machinery by the landowner.

The one radiocarbon date from the structure (cal AD I280-1420, 2 sigma age range), as well as the decorated ceramic vessel sherd assemblage from the features and surface collections, suggest that a Middle Caddo period (ca. A.D. 1200-1400) occupation may have been the principal component at the New Hope site. Middle Caddo period components in the Lake Bob Sandlin area are permanent, year-round, sedentary settlements of horticultural peoples. These Caddo peoples located their settlements in widely dispersed settings that were on well-drained and elevated landforms (see Nelson and Perttula 2003: Figure 23), near areas where wood and grass was plentiful for house construction, as well as near fresh drinking water and arable soils. 


\section{Acknowledgments}

We thank Kenneth L. Beck for permission to investigate the New Hope site. T. Clay Schultz prepared final versions of the two feature maps for this article.

\section{References Cited}

Nelson, B. and T. K. Perttula

2003 Archeological Survey along the Lake Bob Sandlin Shoreline, Camp, Franklin, and Titus Counties, Texas. Report of Investigations No. 46. Archeological and Environmental Consultants, LLC, Austin.

Nelson, B. and M. Turner

1997 The Middle Caddoan Period in the Big Cypress Creek Drainage Basin. Journal of Northeast Texas Archaeology 10:1-11.

Perttula, T. K.

2004 The Prehistoric and Caddoan Archeology of the Northeastern Texas Pineywoods. In The Prehistory of Texas, edited by T. K. Perttula, pp. 370-407. Texas A\&M University Press, College Station.

Suhm, D. A. and E. B. Jelks (editors)

1962 Handbook of Texas Archeology: Type Descriptions. Special Publication No. 1, Texas Archeological Society, and Bulletin No. 4, Texas Memorial Museum, Austin. 
Appendix 1, Beta Analytic, Inc. Radiocarbon Data Form 


\section{CALIBRATION OF RADIOCARBON AGE TO CALENDAR YEARS}

(Variables: $\mathrm{C} 13 / \mathrm{C} 12=-25.8$ :lab. mult $=1$ )

La bor ato ry number: Beta-210581

Conventional radiocarbon age: $620 \pm 60 \mathrm{BP}$

2 Sigma calibrated result: Cal AD 1280 to 1420 (Cal BP 670 to 530) ( $95 \%$ probability)

In te rcept data

Intercepts of radiocarbon age

with calibration curve: Cal AD 1310 (Cal BP 640) and

Cal AD 1360 (Cal BP 590) and

Cal AD 1390 (Cal BP 560)

1 Sigma calibrated result: Cal AD 1290 to 1410 (Cal BP 660 to 540)

( $68 \%$ probability)

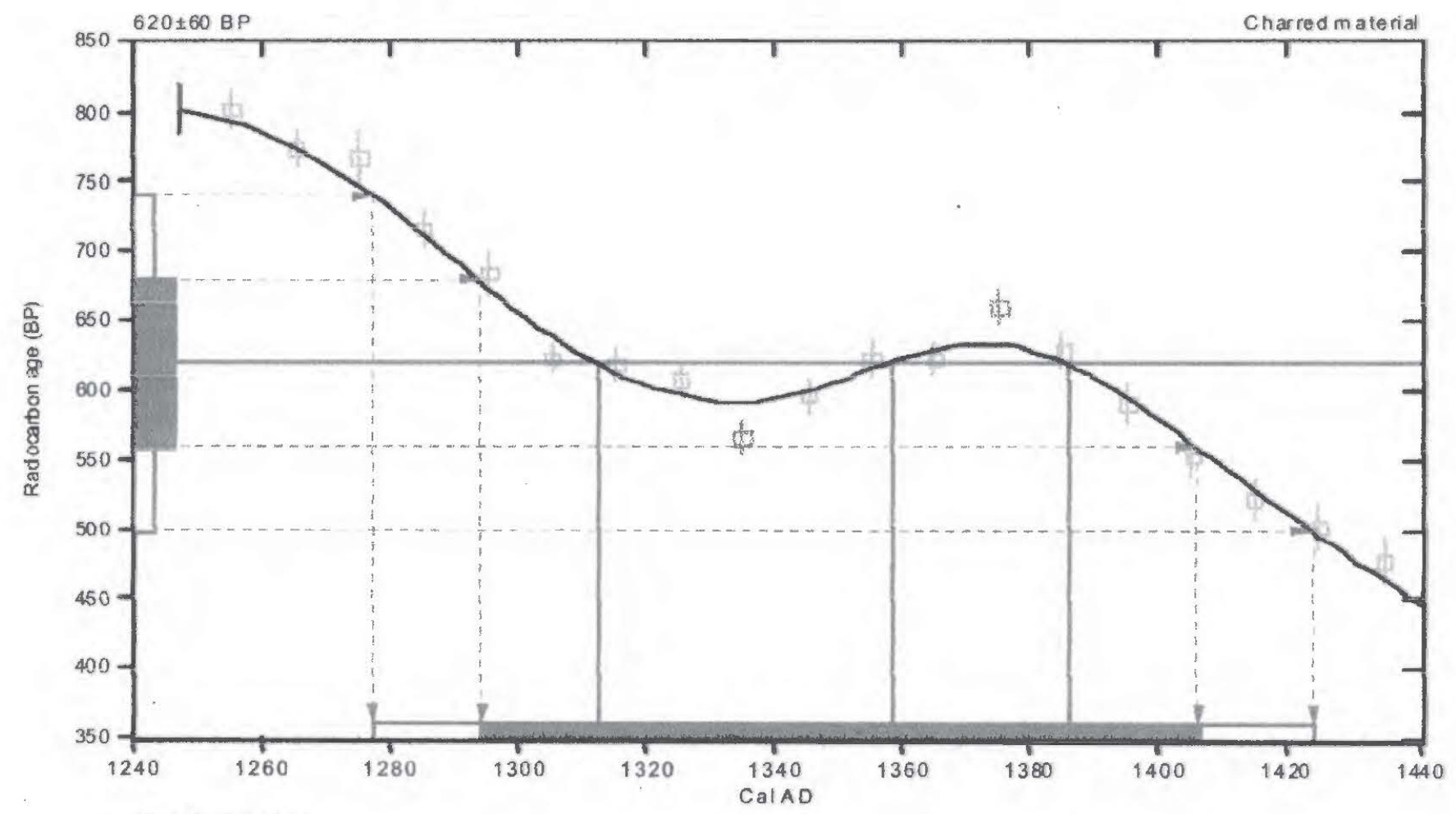

References:

Datubase used

INTC.AL 98

Calibration Datubase

Editorial Con memt

Stuiver, M., vander Plicht. H, 1998. Radiocarbom 40(3), pxii-xiii

INTCAL98 Radiecarbon Age Calibration

Stuiver, M. et. al.. 1998. Radiocarbon 40(3), p1041-1083

Mathe masics

A Sim plified Approach to Calibrating Cld Dutes

Talma, A.S., Fogel, J. C. 1993. Rudiocarbon 35(2), p317-322 


\title{
Human Remains from the Millsey Williamson Site (41RK3), Rusk County, Texas
}

\author{
Diane E. Wilson
}

Bioarchaeological data collection for this article utilized standard techniques described in Buikstra and Ubelaker 1994's Standards for Data Collection from Human Skeletal Remains and the Texas A\&M University, Physical Anthropology Laboratory Data Form. This sample is limited to one bone fragment that was recently recovered eroding from the Millsey Williamson site (4IRK3). The bone fragment was found in association with historic Caddo ceramics and European trade goods (i.e., beads).

The bone fragment was from the right side of the occipital at the occipital protuberance. Only part of the internal occipital protuberance and inferior nuchal line were represented. The fragment was approximately $33.3 \mathrm{~mm}$ wide and $43.3 \mathrm{~mm}$ tall. It is not possible to determine sex from the remains represented, nor to refine the age category beyond that of an adult. Although the Caddo practiced cranial modeling, the fragment was too small to determine if cranial modeling was present.

The cortical surface of the bone was weathered and appeared to have suffered alternate periods of wetting and drying as well as some period of surface exposure. The fragment appeared to be the result of a dry bone fracture of indeterminate force. The high degree of surface erosion likely impacted evidence of taphonomic processes. No evidence of cultural modification of the dead was present, including burning or cut marks. No evidence of biological modification, such as tooth or root marks, of the bone was present. There was no evidence of geological modification either. The cortical bone exhibited an extreme amount of collagen loss; as seen in the chalky, flaking, dry surface. This corresponded to Behresmeyer's (1978) Stage 3. Only minimal abrasion was observed; although exfoliation was moderate and likely the result of surface exposure. Pitting was also moderate and probably the result of acid etching in ground water or soil. Bone polishing from abrasion was absent.

No pathologies were observed. It was not possible to determine standard measurements or non-metric traits from the single bone fragment.

In summary, one individual was represented from the Historic Caddo skeletal remains reported on here. The state of preservation of these remains was relatively poor, but only one bone fragment was analyzed and it is not known how long that fragment had been exposed to the elements. Because of the lack of material and poor state of preservation it was not possible to make metric, non-metric, and paleopathological observations on the osteological remains. Cultural affiliation of the individual has to be based on archaeological context in which the remains were found with Historic Caddo ceramics and trade goods. Many other historic Caddo burials with similar associated artifacts have been reported from the Millsey Williamson site over the last 40+ years (see Jones 1968) 


\section{References Cited}

Behrensmeyer, A. K.

1978 Taphonomic and Ecologic Information from Bone Weathering. Paleobiology $4: 150-162$.

Buikstra, J., and D. Ubelacker (editors)

2004 Standards for Data Collection from Human Skeletal Remains. Research Series No. 44. Arkansas Archeological Survey, Fayetteville.

Jones, B. C.

1968 The Kinsloc Focus: A Study of Seven Historic Caddoan Sites in Northeast Texas. Master's thesis, Department of Anthropology, University of Oklahoma, Norman. 